\title{
Association of hsCRP and soluble fraction of E-selectin with diabetic and non-diabetic individuals
}

Subinay Datta, Mrinal Pal, ${ }^{*}$ Amit Kumar Pradhan, Joydeep Ghosh, Rajarshi Rahut, Amrita Ganguly, Subhadeep Basu

Department of Biochemistry, Burdwan Medical College, Burdwan, West Bengal, India

Accepted on

January 14th, 2014

DOI Name

http://dx.doi.org/10.3126/jaim.v3i1.10697

\section{Keywords}

Endothelial dysfunction, high sensitive C-reactive protein, soluble E-selectin, Inflammatory marker

\section{Citation}

Subinay Datta, Mrinal Pal, Amit Kumar Pradhan, Joydeep Ghosh, Rajarshi Rahut, Amrita Ganguly, Subhadeep Basu. Association of hsCRP and soluble fraction of E-selectin with diabetic and non-diabetic individuals. Journal of Advances in Internal Medicine 2014;03(01):17-22.

\section{ABSTRACT}

Background and aims: It is known that endothelial dysfunction and low-grade inflammation are important element of diabetic complications. The soluble $\mathrm{E}$-selectin is a marker of endothelial dysfunction and C-reactive protein is the most important inflammatory marker. The present study is done to investigate the effect of diabetes on these two markers.

Methods: The present hospital based case control study was conducted in the department of Biochemistry with the collaboration of department of Medicine of Burdwan Medical College, Burdwan, west Bengal India. All subjects were selected by simple random sampling between March 2011 and May 2013. Blood level of these soluble E-selectin and high sensitive C-reactive protein were measured in two hundred diabetic and two hundred age, sex and other non-modifiable as well as modifiable risk factors matched non-diabetic healthy controls.

Results: Compared with control value of high sensitive C-reactive protein and soluble E-selectin levels were higher in diabetic subjects $(p<0.001)$. Our present study shows that levels of adhesion molecules and high sensitive $\mathrm{C}$-reactive protein were higher in diabetic than non-diabetic.

Conclusion: These data suggested that an increased level of inflammatory markers and adhesion molecules among diabetic compared with non-diabetic subjects. This suggests that chronic uncontrolled hyperglycemia contributes to progression of atherosclerosis associated with life-threading complications in middle-aged diabetic patients.

\section{INTRODUCTION}

Diabetes is characterized by hyperglycemia and metabolic abnormalities due to decreased insulin level or action, causing metabolic and physiological changes in various organs. [1] It is also associated with disturbances concerned with protein, carbohydrate and lipid metabolism. [2] The reduced uptake of glucose into muscle and adipose tissue leads to chronic extra cellular hyperglycemia that results in tissue damage and micro as well as macrovascular complications in both type I and II Diabetes Mellitus. $[3,4]$ The development of endothelial dysfunction is considered an important element of diabetic microvascular disease. [5] The adherence of circulating leucocytes to dysfunctional endothelium and their subsequent transmigration into the arterial intima is the subsequent step of the complication. The recruitment of leucocytes into the tissues is dependent on a multiple cascade of events mediated by distinct adhesion molecules. [6-8] The soluble fraction of

\footnotetext{
* Corresponding author

Dr. Mrinal Pal

Department of Biochemistry

Burdwan Medical College, Burdwan, West Bengal, India

Email: mrinalpal77@rediffmail.com
} 
adhesion molecules are found in serum. [9] E-selectin is a leukocyte adhesion molecule specific to endothelial cells, and soluble E-selectin is a marker of endothelial activation. [10-13] It may reflect a variety of pathophysiological conditions related to inflammation. [14] There is a definite low-grade systemic inflammation in diabetes mellitus. [15] Among several markers of inflammation CRP is a pentameric protein produced by the liver, has emerged as the "golden marker of inflammation". $[2,16]$ So, current study focuses on association of hsCRP as an inflammatory marker and sE-selectin as a marker of inflammation with hyperglycemia to detect prognostic implication in both micro and macro-vascular complication of uncontrolled diabetes mellitus. The mechanisms underlying this finding remain unexplained, but connection with abnormal endothelial function and chronic low grade inflammation in patients with type 2 DM remain unknown. So, the present study was to investigate the relation with abnormal endothelial function and chronic low grade inflammation in patients with type 2 DM.

\section{MATERIAL AND METHODS}

\section{Selection of subjects}

The present study was conducted in the department of Biochemistry with the collaboration of department of Medicine of Burdwan Medical College, Burdwan, West Bengal. Two hundred out-patients having age 45-69 years suffering from uncontrolled diabetes mellitus (plasma glucose $>110 \mathrm{mg} / \mathrm{dl}$, $\mathrm{HbA} 1 \mathrm{C}>8 \%$ of total $\mathrm{Hb}$ ) with no history or clinical symptoms of cerebro-vascular disease or cardiovascular disease such as infarction and unstable angina, chronic and/or acute inflammatory disease, and malignancy were recruited in this study. Two hundred non-diabetic subjects, who were attended at out-patients department and matched with age, sex, blood pressure, lipid profile, smoking habit, BMI selected as controls as all these factor influence the level of hsCRP. All subjects were selected by simple random sampling between March 2011 and May 2013. All subjects were recruited consecutively and informed consent in accordance with the principles of the Declaration of Helsinki was obtained. [17] The selected study population were from Burdwan district and adjoining areas. Diabetic patients consisted of aged of $58.5 \pm 6.3$ years and nondiabetic subjects consisted of $56.6 \pm 7.9$ years. Hypertension was defined by either prior diagnosis, current treatment with an anti-hypertensive agent, or blood pressure $>160 / 95 \mathrm{mmHg}$ on three consecutive measurements. The number of cigarettes smoked daily and the duration of smoking were recorded during direct interviews. [18] The subjects were classified as being either never-smokers, ex-smokers (if they had ceased smoking for more than 1 month), or current smokers. Packyears were expressed as the numbers of packs per day $X$ the duration of smoking (years).

\section{Anthropometric measurements}

Weight and height measurements were obtained, using standardized technique. [19] BMI was calculated as the weight in kilograms divided by the square of height in meters. Blood pressure was recorded in the sitting position by using the right arm to the nearest $2 \mathrm{~mm} \mathrm{Hg}$ with a mercury Sphygmomanometer.

\section{Collection of samples}

All parameters were assayed from 12 hour fasting blood samples obtained from cases

and controls. The samples were divided into three aliquots. The first one was collected in oxalate and fluoride vial for obtaining plasma for fasting glucose estimation, second one in plain vial for obtaining serum for insulin, lipid profile, hsCRP and $\mathrm{sE}$-selectin estimation and third one in EDTA containing vial for $\mathrm{HbA}_{1 \mathrm{C}}$ assays. All the parameters were estimated within 24 hours.

\section{Parameters assay}

Quantitative estimation of plasma glucose was done by Glucose oxidase and Peroxidase method [20] from the separated plasma by using the autoanalyzer ERBA XL 600 . Using commercially available Hemoglobin $A_{1 C}$ kit supplied by Siemens Company did Hemoglobin $A_{1 C}$ test. It implies the principle of turbidimetric inhibition immunoassay (TINIA). This company also supplied total $\mathrm{Hb}$ kit for estimation total $\mathrm{Hb}$ by alkaline hematin method. Serum insulin was assayed by ELISA kit AccuBind from Monobind Inc. USA. Both the inter- and intra-assay CVs were below 3\%. [21,22] No cross reactivity with $C$-peptide was detected. Homoeostatic model assessments (HOMA) of steady state $\beta$ cell function ( $\% \beta$ ), insulin sensitivity (\% S) and insulin resistance (HOMA IR) is computed with the formula that is fasting plasma glucose $(\mathrm{mmol} / \mathrm{l})$ times fasting serum insulin (mIU/l) divided by 22.5. [23] Among the lipid profile serum total cholesterol, triglyceride (TG) and high density lipoprotein (HDL) were assayed by Cholesterol Oxidase-peroxidase (CHOD-PAP), glycerol-3-phosphate oxidase (GPO), polyanion precipitation methods respectively using semi-auto analyser. Serum very low-density lipoprotein (VLDL) was calculated by dividing the value of TG by 5 and serum LDL was obtained by Friedewald equation. [24] For measurement of sE-selectin, serum samples were analysed in duplicate using the single-step sandwich ELISA method. [25] The inter- and intra-assay coefficients of variation (CV) were below $5 \%$ and $7 \%$, respectively. Serum hsCRP was measured by Sandwich enzyme linked immunosorbant assay (ELISA) [26] with a lower detection limit $0.03 \mathrm{mg} / \mathrm{L}$. Consistent with recent recommendations from the centres for Disease control and prevention, a CRP cut point of $3 \mathrm{mgs} / \mathrm{L}$ was used to differentiate high risk and low risk groups. [2]

\section{Statistical analysis}

The data for biochemical analysis was subjected to standard statistical analysis using the Statistical Package for Social Science (SPSS) 11.5 software for windows. 


\section{RESULT}

The personal profiles and clinical parameters of all the subjects under study are shown in Table 1.

Table 1: Personal profile and clinical details of healthy persons and patients suffering from Diabetes mellitus

\begin{tabular}{|c|c|c|c|}
\hline Characteristics & $\begin{array}{l}\text { Healthy } \\
\text { persons }\end{array}$ & $\begin{array}{l}\text { Patients suffering from } \\
\text { Diabetes mellitus }\end{array}$ & $p$ value \\
\hline$n$ & 200 & 200 & \\
\hline Age & $58.1 \pm 5.4$ & $57.8 \pm 6.3$ & 0.175 \\
\hline $\begin{array}{ll}\text { Sex: } & \text { Males } \\
& \text { Females }\end{array}$ & $\begin{array}{c}104 \\
96\end{array}$ & $\begin{array}{c}107 \\
93\end{array}$ & 0.152 \\
\hline $\mathrm{BMI}\left(\mathrm{Kg} / \mathrm{m}^{2}\right)$ & $23.2 \pm 2.8$ & $23.4 \pm 2.6$ & 0.285 \\
\hline $\begin{array}{l}\text { Smoking habit } \\
\text { (Current / Ex-smoker / } \\
\text { Never-smoker) }\end{array}$ & $61 / 38 / 101$ & $59 / 39 / 102$ & 0.112 \\
\hline Hypertension (+/-) & $93 / 107$ & $86 / 114$ & 0.128 \\
\hline $\begin{array}{l}\text { Fasting plasma glucose } \\
\text { (mg/dl) }\end{array}$ & $83 \pm 21.56$ & $198 \pm 87.45$ & 0.0002 \\
\hline $\begin{array}{l}\text { Fasting plasma insulin } \\
\text { (pmole/L) }\end{array}$ & $52 \pm 19.3$ & $95 \pm 38.6$ & 0.0017 \\
\hline $\begin{array}{l}\text { Insulin resistance } \\
\text { (HOMA IR) }\end{array}$ & $1.8 \pm 1.2$ & $4.3 \pm 2.7$ & 0.0011 \\
\hline $\mathrm{HbA}_{1 \mathrm{C}}(\%)$ & $5.4 \pm 0.39$ & $9.5 \pm 1.1$ & 0.001 \\
\hline $\begin{array}{l}\text { Total cholesterol } \\
\text { (mmole/L) }\end{array}$ & $5.3 \pm 0.7$ & $5.48 \pm 0.82$ & 0.11 \\
\hline Triglyceride (mmole/L) & $0.134 \pm 0.2$ & $0.135 \pm 0.22$ & 0.19 \\
\hline $\begin{array}{l}\text { HDL-cholesterol } \\
\text { (mmole/L) }\end{array}$ & $1.52 \pm 0.45$ & $1.58 \pm 0.51$ & 0.09 \\
\hline $\begin{array}{l}\text { LDL-cholesterol } \\
\text { (mmole/L) }\end{array}$ & $2.7 \pm 1.1$ & $2.8 \pm 0.4$ & 0.17 \\
\hline
\end{tabular}

BMI means Body Mass Index; $\mathrm{n}$ = number of cases; HOMA IR means Homoeostatic model assessments (HOMA) of steady state $\beta$ cell function ( $\% \beta)$, insulin sensitivity $(\% S)$ and insulin resistance; $\mathrm{HDL}=$ High Density Lipoprotein: $\mathrm{LDL}=$ Low Density Lipoprotein; Value are mean \pm SD.

Serum sE-selectin and hsCRP were found at significantly higher levels in diabetic patients when compared with non-diabetic subjects as shown in the Table 2.

Table 2 Concentration of serum sE-selectin and hsCRP in cases suffering from Diabetes mellitus and controls

\begin{tabular}{lcc}
\hline \multicolumn{1}{c}{ Category } & $\begin{array}{c}\text { Concentration } \\
\text { of serum sE- } \\
\text { selectin }(\mu \mathrm{g} / \mathrm{L})\end{array}$ & $\begin{array}{c}\text { Concentration } \\
\text { of serum hsCRP } \\
(\mathrm{mg} / \mathrm{L})\end{array}$ \\
\hline Diabetes & $54 \pm 12.8$ & $3.6311 \pm 0.94$ \\
Control & $41 \pm 16.2$ & $0.6711 \pm 0.59638$ \\
Diabetes Vs Control & $<0.001$ & $<0.001$ \\
\hline
\end{tabular}

Values are mean $\pm S D ; P>0.05$ not significant; $P<0.001$ highly significant.
In table It is shown that a very high percentage of diabetes mellitus cases have serum hsCRP level more than $3 \mathrm{mg} / \mathrm{l}(82 \%)$, hence falling in high risk group whereas only $18 \%$ percent were having lower concentration.

Table 3 :Distribution of cases suffering from uncontrolled diabetes mellitus according to their serum concentration of hsCRP in serum

\begin{tabular}{ccc}
\hline $\begin{array}{c}\text { Concentration } \\
\text { of serum hsCRP } \\
(\mathrm{mg} / \mathrm{l})\end{array}$ & $\begin{array}{c}\text { Total number of cases }(\mathrm{n}=200) \\
\text { Number of cases } \\
\text { in each group }\end{array}$ & $\begin{array}{c}\text { \% of cases in } \\
\text { each group }\end{array}$ \\
\hline$<1$ & 4 & 2 \\
$1-3$ & 32 & 16 \\
$>3$ & 164 & 82 \\
\hline
\end{tabular}

\section{DISCUSSION}

There is several evidence that low grade systemic inflammation is associated with diabetes mellitus [15] as well as atherosclerosis. $[27,28]$ The inflammatory cell types such as monocyte-derived macrophages and lymphocytes found in the atheroma. [29] These cells in the atherogenous plaque release several inflammatory mediators like cytokines and chemokines which in turn increase the plasma concentration of CRP. [30] C-reactive protein levels for normal adults are usually taken as $<10 \mathrm{mg} / \mathrm{l}$. To measure the CRP at such lower concentration high sensitivity assays have been developed, known as hsCRP. The hsCRP test has good standardization, precision, has a low cost and least pre-analytical variances In present study it is observed that the rise of hsCRP was highly significant in cases as compared to control group as shown in the several previous studies. [2,31] Several studies have found that hsCRP has sufficient risk prediction value for atherosclerosis. [32-34] The level for predicting low risk for atherosclerotic event has been recommended $<1 \mathrm{mg} / \mathrm{l}$, average at $1-3 \mathrm{mg} / \mathrm{l}$ and high risk at $>$ $3 \mathrm{mg} / \mathrm{l}$. [5] In present study it has also been shown that a very high percentage of diabetes mellitus cases have serum hsCRP level more than $3 \mathrm{mg} / \mathrm{l}(82 \%)$, hence falling in high risk group whereas only $18 \%$ percent were having lower concentration.

It has long been proposed that damage to the endothelium is important in the development and/or progression of atherosclerosis, [35] and increased levels of endothelial cell markers in the plasma of subjects who go onto suffer adverse cardiovascular events support this concept. [36,37] Among the most commonly used endothelial cell markers are von Willebrand factor, soluble thrombomodulin, and soluble E-selectin. [11-13] In present study it was found that an important marker of endothelial dysfunction sE-selectin, was found at significantly higher levels in diabetic patients than in non-diabetic subjects. This finding was well corroborated 
with several previous studies. [38-47] The development of endothelial dysfunction is considered an important element of diabetic microvascular disease. Endothelial dysfunction as seen in diabetes is associated with altered production of leucocyteadhesive molecules, e.g., E-selectin and vascular cell adhesion molecule 1 (VCAM-1). These molecules are produced by the activated endothelium, and they are prerequisites for the adhesion and extravasation of leukocytes. [48] In addition, it has been suggested that E-selectin is involved in the angiogenic process. [49] Several studies have found elevated circulating levels of the soluble, shedded part of E-selectin in diabetes, [50-53] particularly among patients with microvascular disease. [54,55] Moreover, an increased expression of these molecules has been found both in the arterial wall $[56,57]$ and

\section{REFERENCES}

1. Genet S, Kale RK, Baquer NZ. Alterations in antioxidant enzymes and oxidative damage in experimental diabetic rat tissues. Effect of vanadate and fenugreek (Trigonella foenum graecum). Mol Cell Biochem 2002;236:7-12. http://dx.doi.org/10.1023/A:1016103131408

2. Amanullah S, Jarari $A$, Govindan $M$, et al. Association of hs-CRP with Diabetic and Non-diabetic individuals. Jordan Journal of Biological Sciences 2010;3:7-12.

3. Brownlee $M$, Cerami.A. Biochemistry of the complications of diabetes mellitus. Annu rev Bioche. 1981;50:385-432.

http://dx.doi.org/10.1146/annurev.bi.50.070181.002125

4. Luscher TF, Creager MA, Bckman JA, et al. Diabetes and vascular disease: Pathophysiology , Clinical consequences and medical therapy: Part II. Circulation 2003;13:1655-61.

http://dx.doi.org/10.1161/01.CIR.0000089189.70578.E2

5. Knudsen ST, Foss $\mathrm{CH}$, Poulsen PL, et al. E-selectininducing activity in plasma from type 2 diabetic patients with maculopathy. Am J Physiol Endocrinol Metab 2002;284: E1-E6.

6. Carter AM, Grant PJ. Vascular homeostasis, adhesion molecules, and macrovascular disease in non-insulindependent diabetes mellitus. Diabet Med 1997;14:42332.

http://dx.doi.org/10.1002/(SICI)10969136(199706)14:6<423::AID-DIA421>3.0.CO;2-F

7. Ross R. The pathogenesis of atherosclerosis an update. N Engl J Med 1986;314:488-500.

http://dx.doi.org/10.1056/NEJM198602203140806

8. Editorials. Atherosclerosis goes to the wall. Lancet 1992;339:647-8.

http://dx.doi.org/10.1016/0140-6736(92)90798-8

9. Takeuchi $N$, Kawamura $T$,Kanai $A$, et al. The effect of in the glomeruli [58] in diabetes.

\section{CONCLUSION}

In conclusion, our present study showed increased levels of inflammatory markers and adhesion molecules among diabetic compared with non-diabetic subjects. This suggests that chronic uncontrolled hyperglycemia contributes to progression of atherosclerosis associated with life-threading complications in middle-aged diabetic patients.

\section{ACKNOWLEDGEMENT}

Authors are thankful to Professor (Dr).Keya Pal, Mr. Naba Kumar Das and Mr. Chandi Charan Das of Burdwan Medical College and Hospital for constant assistance \& support.

cigarette smoking on soluble adhesion molecules in middle-aged patients with Type 2 diabetes mellitus. Diabetic Medicine 2002;19:57-64.

http://dx.doi.org/10.1046/j.1464-5491.2002.00631.x

10. Kistorp C, Chong AY, Gustafsson F, et al. Biomarkers of endothelial dysfunction are elevated and related to prognosis in chronic heart failure patients with diabetes but not in those without diabetes. Eur J Heart Fail 2008;10:380-87.

http://dx.doi.org/10.1016/j.ejheart.2008.02.012

11. Blann AD, Amiral J, McCollum CN. Soluble endothelial cell markers and adhesion molecules in ischaemic heart disease. Br J Haematol 1996;95:263-5.

http://dx.doi.org/10.1046/j.1365-2141.1996.d01-1921.x

12. Blann AD, Amiral J, McCollum CN. Increased soluble thrombomodulin and soluble E-selectin as predictors of disease following myocardial infarction. Eur J Haematol 1997;58:115-20.

13. Belch JJF, Shaw JW, Kirk G, et al. The white blood cell adhesion molecule E-selectin predicts restenosis in patients with intermittent claudication undergoing precutaneous transluminal angioplasty. Circulation 1997;95:2027-31.

http://dx.doi.org/10.1161/01.CIR.95.8.2027

14. Ceriello A, Falleti E, Bortolotti N, et al. Increased circulating intercellular adhesion molecule-1 levels in type II diabetic patients: the possible role of metabolic control and oxidative stress. Metabolism 1996;45:498-501.

http://dx.doi.org/10.1016/S0026-0495(96)90226-7

15. Dehghan A, Kardys I, de Maat MP, et al. Genetic variation, C-reactive protein levels, and incidence of diabetes. Diabetes 2007;56:872-8.

http://dx.doi.org/10.2337/db06-0922

16. Patel VB, Robbins MA, Topol EJ. C-Reactive Protein: A 
'Golden Marker' For Inflammation And Coronary Artery Disease. Clev Clin J Med 2001;68:521-34.

http://dx.doi.org/10.3949/ccjm.68.6.521

17. World Medical Association Declaration of Helsinki: ethical principles for medical research involving human subjects. J Int Bioethique 2004;15:124-9.

http://dx.doi.org/10.3917/jib.151.0124

18. Ismail AA, Gill GV, Lawton $K$, et al. Comparison of questionnaire, breath carbon monoxide and urine nicotinine in assessing the smoking habits of Type 2 diabetic patients. Diabet Med 2000;17:119-23. http://dx.doi.org/10.1046/j.1464-5491.2000.00230.x

19. Deepa M, Pradeepa R, Rema M, et al. The Chennai Urban Rural Epidemiology Study (CURES): Study design and Methodolgy (Urban component) CURES-1 J Assoc Physicians India 2003;51:863-70.

20. Sacks DB. Carbohydrates. In: Burtis CA, Ashwood ER, Bruns DE, editors. Tietz Textbook of Clinical Chemistry and Molecular Diagnostics. 4th ed. New Delhi: Saunders,Elsevier; 2006. p. 870-1.

21. Even MS, Sandusky CB, Barnard ND, et al. Development of a novel ELISA for human insulin using monoclonal antibodies produced in serum-free cell culturemedium. Clin Biochem 2007;40:98-103.

http://dx.doi.org/10.1016/j.clinbiochem.2006.10.004

22. Morris ER, Dinesen B, Burnett MA, et al. A new ELISA for specific insulin measurements in type II diabetic patients. Biochem Soc Trans 1993;21:25S.

23. Francisco G, Hernandez C, Galard R, et al. Usefulness of homeostasis model assessment for identifying subjects at risk for hypoglycemia failure during the insulin hypoglycemia test. J Clin Endocrinol Metab 2004;89:3408-12.

http://dx.doi.org/10.1210/jc.2003-031883

24. McPherson RA, Pincus MR. Henry's clinical diagnosis and management by laboratory methods. 21. New Delhi: Elsevier; 2007. p. 209.

25. Kawamura $T$, Umemura $T$, Kanai $A$, et al. The incidence and characteristics of silent cerebral infarction in elderly diabetic patients: association with serum-soluble adhesion molecules. Diabetologia 1998;41:911-917.

http://dx.doi.org/10.1007/s001250051007

26. Uotila M, Ruoslanti E, Enguall E. Two-site sandwich enzyme immunoassay with monoclonal antibodies to human alpha fetoprotein. J Immunol Methods 1981;42:11-5. doi: 10.1016/0022-1759(81)90219-2.

http://dx.doi.org/10.1016/0022-1759(81)90219-2

27. Ridker PM. The pathogenesis of atherosclerosis and acute thrombosis relevance to strategies of cardiovascular disease prevention. In: Manson JE, Ridker
PM, Gaziano JM, Hennekens $\mathrm{CH}$, editors. Prevention of myocardial infarction. New York: Oxford University Press; 1996. pp. 32-54.

28. Ridker PM. Inflammation, infection and cardiovascular risk: how good is the clinical evidence. Circulation 1998;97:1671-4.

http://dx.doi.org/10.1161/01.CIR.97.17.1671

29. Fauci AS, Kasper DL, Longo DL, Braunwald E, Hauser SL, Larry Jameson J, Loscalzo J. Harrison's principles of internal medicine. 17ed, New York: Mc Graw Hill Companies; 2008. p. 1502.

30. Pasceri V, Willerson JT, Yeh ETH. Direct proinflammatory effect of C-reactive protein on human endothelial cells. Circulation 2000;102:2165-8.

http://dx.doi.org/10.1161/01.CIR.102.18.2165

31. Li CZ, Xue YM, Gao F, et al. Determination of serum hsCRP in patients with type 2 diabetes mellitus. Di Yi Jhun Yi Da Xne Xne Bao 2004;24:791-3.

32. D'Aiuto $F$, Casas JP, Shah $T$, et al. C-reactive protein $(+1444 C>T)$ polymorphism influences CRP response following a moderate inflammatory stimulus. Atherosclerosis 2005;179:413-7. doi: 10.1016/j. atherosclerosis.2004.10.036.

http://dx.doi.org/10.1016/j.atherosclerosis.2004.10.036

33. Sharma SB, Garg S, Veerwal A, et al. hs-CRP and oxidative stress in young CAD patients. Ind J Clin Biochem 2008;23:334-6. doi: 10.1007/s12291-008-0073-8.

http://dx.doi.org/10.1007/s12291-008-0073-8

34. Rost NS, Wolf PA, Kase CS, et al. Plasma concentration of C-reactive protein and risk of ischaemic stroke and transient ischemic attack: the Framingham study. Stroke 2001;32:2575-9. doi: 10.1161/hs1101.098151.

http://dx.doi.org/10.1161/hs1101.098151

35. Ross R. The pathogenesis of atherosclerosis: a perspective for the 1990s. Nature. 1993;362:801-9.

http://dx.doi.org/10.1038/362801a0

36. BlannAD. Endothelialcelldamageandthe developmentor progression of atherosclerosis. Clin Sci 1999;97:119-21. http://dx.doi.org/10.1042/CS19990158

37. Thompson SG, Kienast J, Pyke SDM, et al. for the ECAT Group. Hemostatic factors and the risk of myocardial infarction or sudden death in patients with angina pectoris. N Engl J Med 1995;332:635-41. http://dx.doi.org/10.1056/NEJM199503093321003

38. Hayward R, Campbell B, Shin YK, et al. Recombinant soluble $\mathrm{P}$-selectin ligand-1 protects against myocardial ischemic reperfusion in cats. Cardiovasc Res 1999;41:65-76.

http://dx.doi.org/10.1016/S0008-6363(98)00266-1 
39. Zhang RL, Chopp M, Jiang N, et al. Anti-intercellular adhesion molecule-1 antibody reduces ischaemic cell damage after transient but not permanent middle cerebral artery occlusion in the Wistar rat. Stroke 1995;26:1438-43.

http://dx.doi.org/10.1161/01.STR.26.8.1438

40. Tsukamoto K, Yokono K, Amano K, et al. Administration of monoclonal antibodies against vascular cell adhesion molecule-1/very late antigen- 4 abrogates predisposing autoimmune diabetes in NOD mice. Cell Immunol 1995;165:193-201.

http://dx.doi.org/10.1006/cimm.1995.1205

41. Tanio JW, Chandrasekar BB, Albelda SM, et al. Differential expression of the cell adhesion molecules ICAM-1, VCAM-1 and E-selectin in normal and posttransplantation myocardium. Circulation 1994;89:17601768.

http://dx.doi.org/10.1161/01.CIR.89.4.1760

42. Kuzu I, Bicknell R, Fletcher CDM, et al. Expression of adhesion molecules on the endothelium of normal tissue vessels and vascular tumours. Lab Invest 1993;69:322-8.43. Ridker PM, Hennekens CH, RoitmanJohnson $B$, et al. Plasma concentrations of soluble intercellular adhesion molecule-1 and risks of future myocardial infarction in apparently healthy men. Lancet 1998;351:88-92.

http://dx.doi.org/10.1016/S0140-6736(97)09032-6

44. Blu“ her M, Unger R, Rassoul F, et al. Relation between glycaemic control, hyperinsulinaemia and plasma concentrations of soluble adhesion molecules in patients with impaired glucose tolerance or type II diabetes. Diabetologia 2002;45:210-6.

http://dx.doi.org/10.1007/s00125-001-0723-3

45. Matsumoto K, Nakamura $\mathrm{H}$, Ueki $\mathrm{Y}$, et al. Correction of hyperglycaemia reduces insulin resistance and serum soluble E-selectin levels in patients with type 2 diabetes mellitus. Diabet Med 2001;18:224-8.

http://dx.doi.org/10.1046/j.1464-5491.2001.00457.x

46. Morigi M, Angioletti S, Imberti $B$, et al. Leukocyteendothelial interaction is augmented by high glucose concentrations and hyperglycemia in a NF-kBdependent fashion. J Clin Invest 1998;101:1905-15.

http://dx.doi.org/10.1172/JCI656

47. Ryysy L, Yki-Jarvinen H. Improvement of glycemic control by 1 year of insulin therapy leads to a sustained decrease in sE-selectin concentrations in type 2 diabetes. Diabetes Care 2001;24:549-54.

http://dx.doi.org/10.2337/diacare.24.3.549

48. Koch $\mathrm{AE}$, Halloran MM, Haskell $\mathrm{CJ}$, et al. Angiogenesis mediated by soluble forms of E-selectin and vascular cell adhesion molecule-1. Nature 1995;376:517-9. http://dx.doi.org/10.1038/376517a0

49. Munro JM. Endothelial-leukocyte adhesive interactions in inflammatory diseases. Eur Heart J 1993;14 (Suppl K);72-77.50. Albertini JP, Valensi P, Lormeau B, et al. Elevated concentrations of soluble E-selectin and vascular cell adhesion molecule-1 in NIDDM. Effect of intensive insulin treatment. Diabetes Care 1998;21:1008-13.

http://dx.doi.org/10.2337/diacare.21.6.1008

51. Bagg W, Ferri C, Desideri G, et al. The influences of obesity and glycemic control on endothelial activation in patients with type 2 diabetes. J Clin Endocrinol Metab 2001;86:5491-7.

http://dx.doi.org/10.1210/jc.86.11.5491

52. Kado S, Nagata N. Circulating intercellular adhesion molecule-1, vascular cell adhesion molecule-1, and E-selectin in patients with type 2 diabetes mellitus. Diabetes Res Clin Pract 1999;46:143-8. http://dx.doi.org/10.1016/S0168-8227(99)00083-2

53. Nomura S, Shouzu A, Omoto $S$, et al. Significance of chemokines and activated platelets in patients with diabetes. Clin Exp Immunol 2000;121:437-43. http://dx.doi.org/10.1046/j.1365-2249.2000.01324.x

54. Fasching $P$, Veitl $M$, Rohac $M$, et al. Elevated concentrations of circulating adhesion molecules and their association with microvascular complications in insulin-dependent diabetes mellitus. J Clin Endocrinol Metab 1996;81:4313-7.

http://dx.doi.org/10.1210/jc.81.12.4313

55. Yoshizawa M, Nagai Y, Ohsawa K, et al. Elevated serum levels of soluble vascular cell adhesion molecule- 1 in NIDDM patients with proliferative diabetic retinopathy. Diabetes Res Clin Pract 1998;42:65-70. http://dx.doi.org/10.1016/S0168-8227(98)00091-6

56. Ribau JC, Hadcock SJ, Teoh K, et al. Endothelial adhesion molecule expression is enhanced in the aorta and internal mammary artery of diabetic patients. J Surg Res 1999;85:225-33.

\section{http://dx.doi.org/10.1006/jsre.1999.5682}

57. Richardson M, Hadcock SJ, DeReske M, et al. Increased expression in vivo of VCAM-1 and E-selectin by the aortic endothelium of normolipemic and hyperlipemic diabetic rabbits. Arterioscler Thromb 1994;14:760-9. http://dx.doi.org/10.1161/01.ATV.14.5.760

58. Hirata K, Shikata K, Matsuda M, et al. Increased expression of selectins in kidneys of patients with diabetic nephropathy. Diabetologia 1998;41:185-92. http://dx.doi.org/10.1007/s001250050888 